\title{
Torrefaction of Food Waste as a Potential Biomass Energy Source
}

\author{
Rahsya Nur Udzaifa Abdul Rahman, Mazni Ismail ${ }^{*}$, Ruwaida Abdul Rasid, and Noor Ida Amalina \\ Ahamad Nordin
}

Faculty of Chemical and Natural Resources Engineering, Universiti Malaysia Pahang,

Lebuhraya Tun Razak 26300, Gambang, Pahang, Malaysia

\begin{abstract}
* Corresponding author:
tel: +60139593067

email:mazni@ump.edu.my

Received: August 3, 2018

Accepted: December 1, 2018

DOI: $10.22146 /$ ijc. 40871

Abstract: Food waste (FW) represents a major component of municipal solid waste (MSW) in Malaysia which causes a negative impact due to poor waste management. One of a promising strategy to reduce the $F W$ is to convert the FW to energy sources through thermal pre-treatment process which known as torrefaction. The aim of this study is to investigate the improvement of chemical properties and energy potential of the torrefied $F W$. The torrefaction of FW was conducted using the tubular reactor to evaluate the influence of temperature $\left(220\right.$ to $\left.260^{\circ} \mathrm{C}\right)$ and residence time (15 to $\left.60 \mathrm{~min}\right)$ on the quality of torrefied FW. The quality of torrefied FW was evaluated using ultimate analysis, proximate analysis, mass yield, energy yield and higher heating value (HHV). From the ultimate analysis, the carbon, $C$ was increased; however, the hydrogen, $H$ and oxygen, $O$ decreased across the torrefaction temperature and residence time. This lead to the increasing of HHV with increased temperature and time. The HHV of the dried FW was improved from 19.15 to $23.9 \mathrm{MJ} / \mathrm{kg}$ after being torrefied at $260^{\circ} \mathrm{C}$ for $60 \mathrm{~min}$. The $\mathrm{HHV}$ indicated that $F W$ has the potential to be utilized as an energy source.
\end{abstract}

Keywords: food waste (FW); municipal solid waste (MSW); torrefaction; HHV

\section{- INTRODUCTION}

Urbanization and population growth generally increased the standard of living and also accompanied by increased in the municipal solid waste (MSW) generation [1]. In 2010, the generation of MSW in the world was approximately 10.9 million tons per year [2]. It is predicted that the generation of MSW will increase up to 14.9 million tons in 2020 and 16.0 million tons in 2030 [1]. In Malaysia, the food waste (FW) represents a large fraction of MSW which is $45 \%$ [3] where $20 \%$ of the FW are foods that are still fit for consumptions [4].

Nowadays, most of the MSW is disposed at landfill or dumpsite, and only a small amount ends up in incinerator [5]. However, disposal of FW through landfilling is becoming more challenging because the existing landfill is filling up at a very fast rate. At the same time, locating a new landfill is also becoming more difficult as space becomes scarce and land price become more expensive, especially in urban areas due to rapid urbanization and industrialization [6].
With the increasing of FW rate every year, the accumulation of FW will cause disposal and pollution problems such as greenhouse gas emission through FW degradation which causes global warming and climate change. One of the promising strategies to reduce the impact of FW on the environment is to convert the FW into an energy source. However, FW is usually characterized by its high moisture content, low calorific value, and energy density compared to fossil fuel [7]. This is a clear indication of the need for having pretreatment of FW prior to its utilization for efficient energy conversion. This pre-treatment can be done by torrefaction.

Torrefaction is a thermal pre-treatment where the raw material is heated in a nitrogen atmosphere at a temperature range of 200 to $300{ }^{\circ} \mathrm{C}$ [7]. Torrefaction provides higher calorific value or energy density, more brittle fibers which improve grindability, lower moisture content which improves ignitability and reactivity [8]. However, the product obtained is very dependent on the 
experimental conditions applied during torrefaction [9]. During torrefaction, the volatile matter and water which contained lower energy are removed, thus enhancing the amount of energy of the product [9]. The produced solid fuels has properties close to the coal [9] and can be utilized for combustion and co-firing application [10].

Torrefaction has been conducted on different agricultural byproduct that being left as waste such as oil palm waste [11] including palm kernel shell (PKS), empty fruit bunch (EFB) mesocarp fiber and oil palm frond [1215], bamboo [16] and pine sawdust [17]. There are also some studies on torrefaction of microorganism such as Auricularia auricula-judae, which is an edible fungi species [18]. At the moment, only a small number of work had been published on the FW torrefaction.

There are also studies on torrefaction of FW from different countries such as Korea [8] and Africa [8]. At the moment, only Samad et al. [19] studied torrefaction of FW in Malaysia. Therefore, there are still numerous issues that need to be addressed before the torrefied FW can be commercialized.

The aim of this study is to investigate the improvement of chemical properties and energy potential of the torrefied FW in Malaysia. The torrefaction was conducted using a tubular reactor at a temperature range of 220 to $260{ }^{\circ} \mathrm{C}$ for 15 to $60 \mathrm{~min}$, under an inert condition.

\section{- EXPERIMENTAL SECTION}

\section{Materials}

FW samples was collected from a landfill in Kampung Sungai Ikan, Kuala Terengganu, Malaysia which contained rice $(21 \%)$, fruits $(21 \%)$, vegetables (16\%), seafood (7\%), bones (19\%), processed food (7\%), and chicken (9\%). The collected samples were dried at $105^{\circ} \mathrm{C}$ overnight in the oven [8]. Then, the dried FW was ground and then sieved to get particles size ranging from $500 \mu \mathrm{m}$ to more than $1 \mathrm{~mm}$. Table 1 listed the moisture content, HHV and elemental of the raw FW samples used in this present work.

\section{Procedure}

Torrefaction of FW was conducted using a tubular
Table 1. The properties of the untreated FW

\begin{tabular}{lr}
\hline FW Properties & \\
\hline Moisture content (\%, wet) & 66.28 \\
HHV (MJ/kg, dry) & 19.76 \\
Elemental (wt.\%, dry) & \\
C & 44.72 \\
H & 7.13 \\
N & 3.49 \\
S & 0.40 \\
O & 44.26 \\
\hline
\end{tabular}



Fig 1. Test station of torrefaction process

reactor. Three grams of FW was inserted into reactor and the reactor was placed inside the furnace as shown in Fig. 1 [8]. The reactor was purged with $10 \mathrm{~mL} / \mathrm{min}$ of $\mathrm{N}_{2}$ [20] for $3 \mathrm{~min}$ to remove impurities in the reactor. After that, the temperature was set to the desired temperature (from 220 until $260{ }^{\circ} \mathrm{C}$ with $20{ }^{\circ} \mathrm{C}$ increment). The torrefaction lasted for 15, 30 and $60 \mathrm{~min}$ after torrefaction temperature has been reached. When the torrefaction experimental was completed, the temperature of the reactor is reduced to atmospheric temperature before weighed the FW. Fig. 1 shows the test station of the torrefaction process.

\section{Torrefied biomass characterization}

The ultimate analysis, proximate analysis and higher heating value (HHV) were measured for both untreated and torrefied food waste. The proximate analysis was conducted using TGA-50 Shimadzu. The 
samples were heated from 30 to $1000{ }^{\circ} \mathrm{C}$ with $10^{\circ} \mathrm{C} / \mathrm{min}$ heating rate and flow of $10 \mathrm{~mL} / \mathrm{min} \mathrm{N}_{2}$. Elemental analysis of the raw and torrefied sample was conducted using the Perkin Elmer 2400 Series. The HHV, the energy content of the torrefied FW was calculated using Eq. (1) [21]. The ash content was calculated based on the remaining weight loss in the proximate analysis. The mass and energy yield was calculated by Eq. (2) and (3) respectively [7].

$\mathrm{HHV}=0.3517 \mathrm{C}+1.1626 \mathrm{H}+0.104 \mathrm{~S}-0.11100$

Mass yield $\left(\mathrm{Y}_{\mathrm{M}}\right)=\frac{\text { mass after torrefaction }}{\text { mass before torrefaction }} \times 100 \%$

Energy yield $\left(\mathrm{Y}_{\mathrm{E}}\right)=\mathrm{Y}_{\mathrm{M}} \times \frac{\mathrm{HHV}(\text { torrefied sample })}{\mathrm{HHV}(\text { raw sample })} \times 100 \%$

\section{- RESULTS AND DISCUSSION}

\section{Ultimate Analysis}

The ultimate analysis of the untreated and torrefied food waste is as shown in Table 2 across the different torrefaction temperature and residence time. Table 2 shows the increase in the carbon content (from 44.72 to $50.61 \%$ ) with increasing temperature. The oxygen content was observed to be decreased from 44.27 to $38.05 \%$. Similarly, when the residence time was increased from 15 to $60 \mathrm{~min}$, the carbon content was also increased, and both the $\mathrm{H}$ and $\mathrm{O}$ content was decreased. The carbon content has the highest value at $60 \mathrm{~min}$ with $54.53 \%$ compared to at $30 \mathrm{~min}$ with $50.61 \%$. This is desirable since the target of the torrefaction process is to increase carbon content which will lead to an increase of the energy density of the solid fuel. However, hydrogen content decreased after
$30 \mathrm{~min}$. The hydrogen content at $60 \mathrm{~min}(6.90 \%)$ was lower than at $30 \mathrm{~min}(7.23 \%)$. These decreased of $\mathrm{H}$ and $\mathrm{O}$ may be due to the release of volatiles such as carbon dioxide, carbon monoxide, and water when longer residence time was applied.

Fig. 2 and 3 illustrate the changes of $\mathrm{O} / \mathrm{C}$ and $\mathrm{H} / \mathrm{C}$ ratio as the torrefaction temperature and time were increased. The ratios are indicators of carbon improvement; in which it is desired to have these values as small as possible (high carbon content). Both $\mathrm{O} / \mathrm{C}$ and $\mathrm{H} / \mathrm{C}$ show a decreasing trend as the process conditions become more severe. When compared to the $\mathrm{O} / \mathrm{C}$ and $\mathrm{H} / \mathrm{C}$ ratio of coal in a van Krevelen diagram in Fig. 4, it can further be clarified that the trend in carbon improvement may be observed, all of which are converging towards the values of coal.

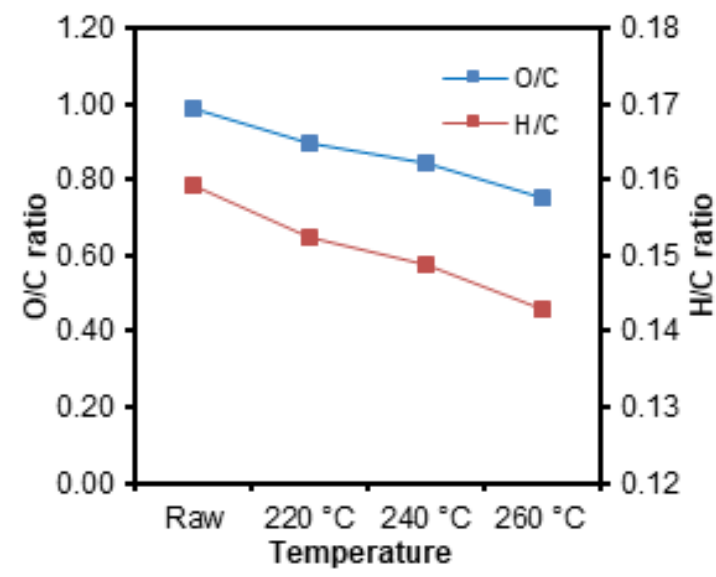

Fig 2. Change of $\mathrm{H} / \mathrm{C}$ and $\mathrm{O} / \mathrm{C}$ ratio on torrefied temperature

Table 2. The ultimate analysis at a different torrefied temperature

\begin{tabular}{|c|c|c|c|c|c|c|c|c|c|}
\hline \multirow{2}{*}{ Condition } & & \multicolumn{7}{|c|}{ Element (\%) } & \multirow{2}{*}{ Reference } \\
\hline & & $\mathrm{C}$ & $\mathrm{H}$ & $\mathrm{N}$ & $S$ & $\mathrm{O}$ & $\mathrm{O} / \mathrm{C}$ & $\mathrm{H} / \mathrm{C}$ & \\
\hline FW Sample & & 44.72 & 7.13 & 3.49 & 0.40 & 44.27 & 0.99 & 0.16 & \multirow{7}{*}{ Current work } \\
\hline \multirow{3}{*}{$\begin{array}{l}\text { Temperature }\left({ }^{\circ} \mathrm{C}\right) \\
(\mathrm{t}=30 \mathrm{~min})\end{array}$} & 220 & 47.23 & 7.19 & 2.94 & 0.16 & 42.48 & 0.90 & 0.15 & \\
\hline & 240 & 48.18 & 7.17 & 3.81 & 0.22 & 40.62 & 0.84 & 0.15 & \\
\hline & 260 & 50.61 & 7.23 & 3.94 & 0.17 & 38.05 & 0.75 & 0.14 & \\
\hline \multirow{3}{*}{$\begin{array}{l}\text { Residence time (min) } \\
\left(\mathrm{T}=260^{\circ} \mathrm{C}\right)\end{array}$} & 15 & 48.11 & 7.50 & 3.75 & 0.15 & 40.49 & 0.84 & 0.16 & \\
\hline & 30 & 50.61 & 7.23 & 3.94 & 0.17 & 38.05 & 0.75 & 0.14 & \\
\hline & 60 & 54.53 & 6.90 & 4.61 & 0.15 & 33.82 & 0.62 & 0.13 & \\
\hline Anglo coal & & 67.29 & 3.48 & 1.58 & 0.35 & 6.72 & 0.10 & 0.05 & Pahla et al. [7] \\
\hline
\end{tabular}




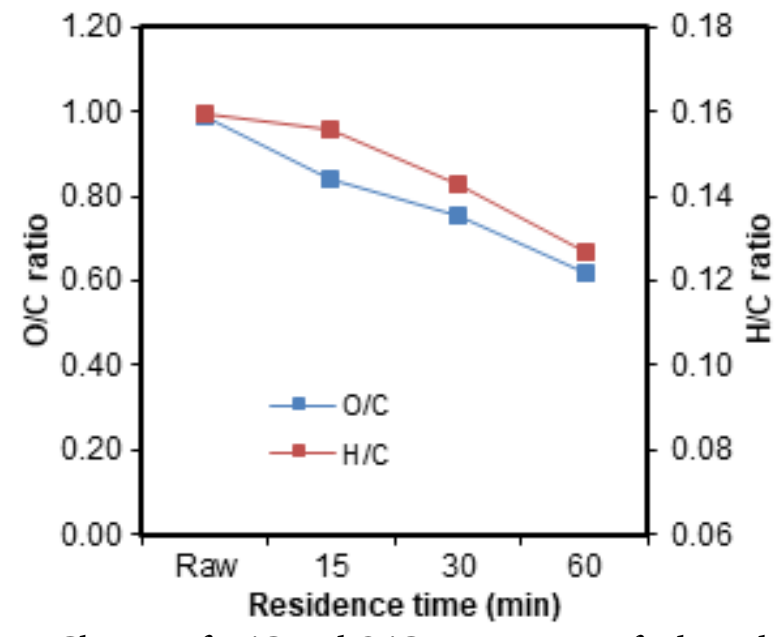

Fig 3. Change of $\mathrm{H} / \mathrm{C}$ and $\mathrm{O} / \mathrm{C}$ ratio on torrefied residence time

\section{Mass Yield, Energy Yield, and High Heating Value}

Heating the FW through torrefaction results in thermal degradation of the samples. The degree of thermal degradation depends on the temperature and residence time. To understand the influence of temperature and residence time on the degree of thermal degradation, the mass yield of the torrefied FW was calculated using Eq. (2). The mass yield is summarized in Table 3 for various temperature and residence time. As can be seen in Table 3, the mass yield was slightly decreased as temperature increased from 220 to $240{ }^{\circ} \mathrm{C}$ (about $2.5 \%$ reduction) when the residence time was varying from 15 to $30 \mathrm{~min}$. However, the mass yield was dramatically decreased as the temperature increased from 240 to $260{ }^{\circ} \mathrm{C}$ (about 11 to $21 \%$ reduction) when the residence time was varying from 30 to $60 \mathrm{~min}$.

The reason for the mass loss is likely due to moisture loss and thermal degradation to form organic compounds such as $\mathrm{H}_{2} \mathrm{O}, \mathrm{CO}, \mathrm{CO}_{2}$ and $\mathrm{CH}_{4}$ [8-9]. The thermal degradation proceeded slowly at a lower temperature but gradually increased as temperature increased from 240 to $260{ }^{\circ} \mathrm{C}$. At $220^{\circ} \mathrm{C}$, the mass loss mainly results from the moisture loss and small degradation of hemicellulose producing light volatiles [8-9]. However, the hemicellulose degradation rate gradually increases as the temperature increased because of disruption of most hydrogen bonds, $\mathrm{C}-\mathrm{C}$ and $\mathrm{C}-\mathrm{O}$ bonds, thus resulting in lower mass yield [8-9].

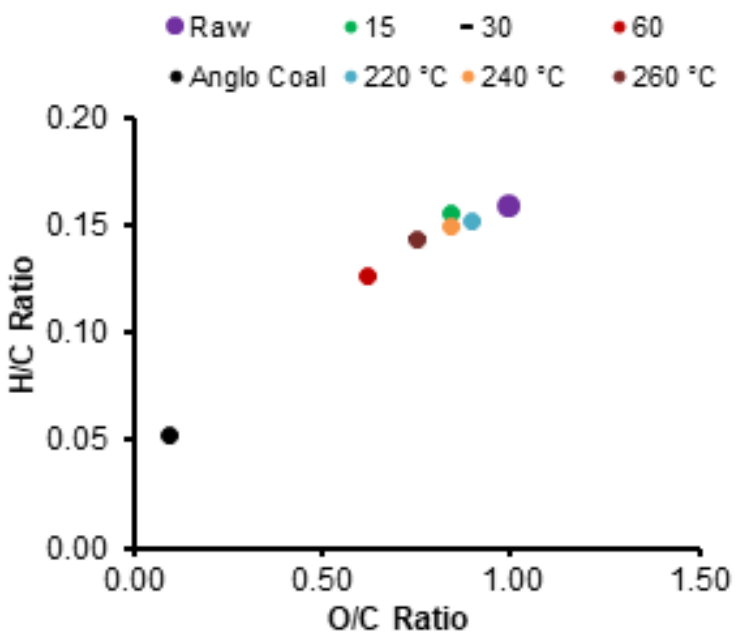

Fig 4. The Van Krevelan diagram

Table 3. The mass yield of torrefied FW

\begin{tabular}{lcc}
\hline Temp $\left({ }^{\circ} \mathrm{C}\right)$ & Time $(\mathrm{min})$ & Mass yield $(\%)$ \\
\hline \multirow{2}{*}{220} & 15 & 94.50 \\
& 30 & 93.37 \\
& 60 & 85.75 \\
\hline \multirow{2}{*}{240} & 15 & 92.18 \\
& 30 & 91.36 \\
& 60 & 84.56 \\
\hline \multirow{2}{*}{260} & 15 & 87.88 \\
& 30 & 81.78 \\
& 60 & 66.95 \\
\hline
\end{tabular}

As mentioned earlier, other than temperature, the mass yield of torrefied FW is also influenced by torrefaction residence time. Table 3 indicates that the mass yield decreases as the residence time increases for each temperature. The mass yield of torrefied FW is decreased from 94.50 to $85.75 \%$ when the residence time is varying from $15 \mathrm{~min}$ to $60 \mathrm{~min}$ at torrefaction temperature of $220^{\circ} \mathrm{C}$. The same trend was observed at the torrefaction temperature of 240 and $260{ }^{\circ} \mathrm{C}$ with a higher reduction of mass yield which is from 92.18 and $87.88 \%$ to 84.56 and $66.95 \%$ respectively. The drop in mass yield was higher for longer residence time was mainly contributed by more degradation took place during the torrefaction process including less reactive component [8].

HHV represent the energy content of the torrefied FW and is one of the keys in the definition of torrefied FW 
Table 4. The HHV and energy yield of torrefied FW

\begin{tabular}{llll}
\hline Condition & & $\begin{array}{l}\text { HHV } \\
(\mathrm{MJ} / \mathrm{kg})\end{array}$ & $\begin{array}{l}\text { Energy } \\
\text { yield }(\%)\end{array}$ \\
\hline Raw & & 19.76 & \\
\hline Temperature $\left({ }^{\circ} \mathrm{C}\right)$ & 220 & 20.98 & 99.12 \\
$(\mathrm{t}=30 \mathrm{~min})$ & 240 & 21.40 & 98.93 \\
& 260 & 22.61 & 93.58 \\
\hline Residence time $(\mathrm{min})$ & 15 & 21.86 & 97.24 \\
$\left(\mathrm{~T}=260^{\circ} \mathrm{C}\right)$ & 30 & 22.61 & 93.58 \\
& 60 & 23.92 & 81.04 \\
\hline
\end{tabular}

product quality. HHV was calculated based on Eq. (1). HHV of produced biochar at 220,240 and $260^{\circ} \mathrm{C}$ with a fixed residence time of $30 \mathrm{~min}$ was presented in Table 4. The HHV for variation of residence time (15 to $60 \mathrm{~min}$ ) with a fixed temperature of $260{ }^{\circ} \mathrm{C}$ is also included in Table 4 . The data indicated that increasing the torrefaction temperature and residence time increased the HHV of torrefied FW.

It can be seen that HHV increment of torrefied FW was in the range of $1-4 \%$. The HHV is increased from 19.76 to $22.61 \mathrm{MJ} / \mathrm{kg}$ as the temperature increased to $260{ }^{\circ} \mathrm{C}$ at $30 \mathrm{~min}$ residence time. The HHV increased to $23.92 \mathrm{MJ} / \mathrm{kg}$ with $60 \mathrm{~min}$ torrefaction residence time which is the highest HHV achieved under the conditions investigated in this study.

According to Pahla et al. [7], C=C, C-C and C-H bonds contain higher energy compared to $\mathrm{O}-\mathrm{H}$ bonds. Therefore, an increase in the carbon content and reduction in the oxygen content in the torrefied FW as the temperature and residence time increased lead to an increase in the HHV.

The energy yield of the produced biochar at various temperature and residence times is also shown in Table 4. They were calculated based on Eq. (3), from the values of the heating values of both raw and torrefied food waste. In Table 4 , it can be seen that when the temperature was increased, the energy yield decreased. A similar observation can be investigated for the residence time, whereby as the residence time was increased, the energy yield was decreased. This is consistent with a study on the torrefaction of food waste [7] as well as the torrefaction of energy crops [22] in which increasing the torrefaction
Table 5. The proximate analysis of torrefied FW

\begin{tabular}{lllll}
\hline \multirow{2}{*}{ Condition } & & \multicolumn{3}{c}{ Element (\%) } \\
\cline { 2 - 5 } & & MC & VM & FC \\
\hline Raw & 4.94 & 64.83 & 30.23 \\
\hline Temperature $\left({ }^{\circ} \mathrm{C}\right)$ & 220 & 4.31 & 59.21 & 36.49 \\
$(\mathrm{t}=30$ min) & 240 & 3.71 & 57.34 & 38.95 \\
& 260 & 3.67 & 54.50 & 41.83 \\
\hline \multirow{2}{*}{ Residence time (min) } & 15 & 4.27 & 58.84 & 36.89 \\
$\left(\mathrm{~T}=260^{\circ} \mathrm{C}\right)$ & 30 & 3.67 & 54.50 & 41.83 \\
& 60 & 2.91 & 47.97 & 49.12 \\
\hline
\end{tabular}

temperature and time are detrimental for the energy yield of the torrefied biomass. As energy yield is a balance in solid biochar that is remaining after the torrefaction with the potential energy that the biochar may be able to generate, without losing too much mass, it may be desired to carry out torrefaction at $260{ }^{\circ} \mathrm{C}$ at 30 min to achieve ideal energy yield.

\section{Proximate Analysis}

Table 5 present the moisture content (MC), volatile matter (VM) and fixed carbon (FC) of torrefied FW (on dry basis) at different temperature and residence time. The MC decreased from 4.94 to $2.91 \%$ as the temperature and residence time increased. The reduction of MC may occur due to the dehydration of remaining moisture after had been pre-dried in the oven prior to the torrefaction [23]. The dehydration of the torrefied biomass increased as higher temperature and longer residence time was applied.

Like MC, the VM of the torrefied FW also decreased as the temperature and residence time increased. The VM was reduced from 64.83 to $47.97 \%$ due to the released volatiles components such as carbon dioxide, carbon monoxide, acetic acid, formic acid, methanol and formaldehyde [24].

In contrast to $\mathrm{MC}$ and $\mathrm{VM}$, the FC increased as the torrefaction temperature and residence time increased. The FC was increased from 30.23 to $49.12 \%$. Similar proximate analysis was also observed by Poudel et al. [8], Martín-Lara et al. [9] and Granados et al. [25]. The increment of FC was in line with the increase of $\mathrm{C}$ content in the ultimate analysis as the temperature and time increased. The increased of FC is the main 
contributor to the rise in HHV of torrefied FW across the temperature and residence time.

\section{- CONCLUSION}

In this study, the improvement of chemical compositions and the energy potential of the torrefied FW at different temperature and time were investigated. The $\mathrm{C}$ content increased while both $\mathrm{H}$ and $\mathrm{O}$ content decreased as the temperature and time increased. This is due to the degradation and volatilization of organic compounds such as $\mathrm{CO}, \mathrm{CO}_{2}$, and $\mathrm{H}_{2} \mathrm{O}$ which lead to an increased in HHV of the torrefied FW. The highest HHV $(23.92 \mathrm{MJ} / \mathrm{kg})$ was obtained at the highest temperature $\left(260{ }^{\circ} \mathrm{C}\right)$ and longest residence time (60 min). Based on van Krevelan diagram, the $\mathrm{C}$ improvement of torrefied $\mathrm{FW}$ are converging towards the value of coal as the temperature and time increased. As a conclusion, FW has the potential to be utilized as an energy source.

\section{- ACKNOWLEDGMENTS}

The authors would like to acknowledge Universiti Malaysia Pahang (UMP) internal grant (RDU1703171) and Mercu RE Solution Sdn. Bhd. for financial support for this work.

\section{- REFERENCES}

[1] Harun, N., Ibrahim, W.H.W., Lukman, M.F., Yusoff, M.H.M., Daud, N.F.S., and Zainol, N., 2018, "Process Simulation of Anaerobic Digestion Process for Municipal Solid Waste Treatment" in Anaerobic Digestion Processes: Applications and Effluent Treatment, Eds., Horan, N., Yaser, A., and Wid, N., $1^{\text {st }}$ ed., Springer, Singapore, 71-83.

[2] Hamid, K.B.A., Ishak, M.Y., and Abu Samah, M.A., 2015, Analysis of municipal solid waste generation and composition at administrative building café in Universiti Putra Malaysia: A case study, Polish J. Environ. Stud., 24 (5), 1969-1982.

[3] Zainu, Z., and Songip, A., 2017, Policies, challenges and strategies for Municipal waste management in Malaysia, J. Sci. Technol. Innovation Policy, 3 (1), 1822.
[4] Star Online, 2015, How Electricity Is Generated in Malaysia, https://www.thestar.com.my/metro/focus /2015/04/22/how-electricity-is-generated-in-Malaysia/

[5] Moh, Y.C., and Abd Manaf, L., 2017, Solid waste management transformation and future challenges of source separation and recycling practice in Malaysia, Resour. Conserv. Recycl., 116, 1-14.

[6] Abd Ghafar, S.W., 2017, Food waste in Malaysia: Trends, current practices and key challenges, FFTC-AP, 19582, 1-12.

[7] Pahla, G., Ntuli, F., and Muzenda, E., 2018, Torrefaction of landfill food waste for possible application in biomass co-firing, Waste Manage., 71, 512-520.

[8] Poudel, J., Ohm, T.I., and Oh, S.C., 2015, A study on torrefaction of food waste, Fuel, 140, 275-281.

[9] Martín-Lara, M.A., Ronda, A., Zamora, M.C., and Calero, M., 2017, Torrefaction of olive tree pruning: Effect of operating conditions on solid product properties, Fuel, 202, 109-117.

[10] Verma, M., Loha, C., Sinha, A.N., and Chatterjee, P.K., 2017, Drying of biomass for utilising in co-firing with coal and its impact on environment - A review, Renewable Sustainable Energy Rev., 71, 732-741.

[11] Uemura, Y., Omar, W.N., Tsutsui, T., and Yusup, S.B., 2011, Torrefaction of oil palm wastes, Fuel, 90 (8), 2585-2591.

[12] Poudel, J., Ohm, T.I., Gu, J.H., Shin, M.C., and Oh, S.C., 2017, Comparative study of torrefaction of empty fruit bunches and palm kernel shell, J. Mater. Cycles Waste Manage., 19 (2), 917-927.

[13] Uemura, Y., Sellappah, V., Trinh, T.H., Hassan, S., and Tanoue, K., 2017, Torrefaction of empty fruit bunches under biomass combustion gas atmosphere, Bioresour. Technol., 243, 107-117.

[14] Hambali, E., and Rivai, M., 2017, The Potential of Palm Oil Waste Biomass in Indonesia in 2020 and 2030, IOP Conf. Ser. Earth Environ. Sci., 65, 012050.

[15] Faizal, H.M., Shamsuddin, H.S., Heiree, M.H.M., Hanaffi, M.F.M.A., Rahman, M.R.A., Rahman, M.M., and Latiff, Z.A., 2018, Torrefaction of 
densified mesocarp fibre and palm kernel shell, Renewable Energy, 122, 419-428.

[16] Chen, W.H., Liu, S.H., Juang, T.T., Tsai, C.M., and Zhuang, Y.Q., 2015, Characterization of solid and liquid products from bamboo torrefaction, Appl. Energy, 160, 829-835.

[17] Gong, C., Huang, J., Feng, C., Wang, G., Tabil, L., and Wang, D., 2016, Effects and mechanism of ball milling on torrefaction of pine sawdust, Bioresour. Technol., 214, 242-247.

[18] Zhang, Y., Yao, A., and Song, K., 2016, Torrefaction of cultivation residue of Auricularia auricula-judae to obtain biochar with enhanced fuel properties, Bioresour. Technol., 206, 211-216.

[19] Samad, N.A.F.A., Jamin, N.A., and Saleh, S., 2017, Torrefaction of municipal solid waste in Malaysia, Energy Procedia, 138, 313-318.

[20] Uemura, Y., Matsumoto, R., Saadon, S., and Matsumura, Y., 2015, A study on torrefaction of Laminaria japonica, Fuel Process. Technol., 138, 133138.
[21] Channiwala, S.A., and Parikh, P.P., 2002, A unified correlation for estimating HHV of solid, liquid and gaseous fuels, Fuel, 81 (8), 1051-1063.

[22] Bridgeman, T.G., Jones, J.M., Shield, I., and Williams, P.T., 2008, Torrefaction of reed canary grass, wheat straw and willow to enhance solid fuel qualities and combustion properties, Fuel, 87 (6), 844-856.

[23] Sabil, K.M., Aziz, M.A., Lal, B., and Uemura, Y., 2013, Effects of torrefaction on the physiochemical properties of oil palm empty fruit bunches, mesocarp fiber and kernel shell, Biomass Bioenergy, 56, 351-360.

[24] Yang, Z., Sarkar, M., Kumar, A., Tumuluru, J.S., and Huhnke, R.L., 2014, Effects of torrefaction and densification on switchgrass pyrolysis products, Bioresour. Technol., 174, 266-273.

[25] Granados, D.A., Ruiz, R.A., Vega, L.Y., and Chejne, F., 2017, Study of reactivity reduction in sugarcane bagasse as consequence of a torrefaction process, Energy, 139, 818-827. 